\title{
Pengaruh Kualitas Sumber Daya Manusia dan Sistem Pengendalian Intern Pada Kualitas Laporan Keuangan Pemerintah Daerah
}

\author{
Ni Nyoman Trisnawati ${ }^{1}$ \\ Dewa Nyoman Wiratmaja ${ }^{2}$ \\ ${ }^{1}$ Fakultas Ekonomi dan Bisnis Universitas Udayana (Unud), Bali, Indonesia \\ email: sukmayantidian@gmail.com / Telp: +6285205142199 \\ ${ }^{2}$ Fakultas Ekonomi dan Bisnis Universitas Udayana (Unud), Bali, Indonesia
}

\begin{abstract}
ABSTRAK
Tujuan dari penelitian ini adalah untuk memperoleh bukti empiris pengaruh kualitas sumber daya manusia dan sistem pengendalian intern pada kualitas laporan keuangan pemerintah daerah Kabupaten Gianyar. Penelitian ini menggunakan data primer yang diperoleh langsung dari responden dengan penyebaran kuesioner. Metode penentuan sampel yang digunakan dalam penelitian ini adalah pendekatan non-probability dengan menggunakan teknik purposive sampling. Sampel yang digunakan dalam penelitian ini sebanyak 33 OPD yang ada di Kabupaten Gianyar. Teknik analisis data yang digunakan dalam penelitian ini adalah analisis regresi linear berganda. Hasil dari penelitian ini menunjukkan bahwa kualitas sumber daya manusia dan sistem pengendalian intern berpengaruh positif pada kualitas laporan keuangan pemerintah daerah. Penelitian selanjutnya diharapkan dapat menggunakan populasi pada lokasi yang berbeda agar hasil penelitian dapat dibandingkan dengan peneliti sebelumnya. Penelitian selanjutnya juga diharapkan dapat mempertimbangkan variabel-variabel lain diluar penelitian ini.
\end{abstract}

Kata kunci: Kualitas sumber daya manusia, sistem pengendalian intern, kualitas laporan keuangan pemerintah daerah.

\footnotetext{
ABSTRACT

The purpose of this study is to obtain empirical of the influence of quality of human resources and internal control system to the quality of financial statements of local government of Gianyar Regency. This study uses primary data obtained directly from respondents with questionnaires spread. The sampling method is nonprobability sampling with purposive sampling technique. The numbers of samples used were 33 OPD in Gianyar Regency. The analysis technique used in this study is multiple linear regression analysis. The results of this study indicate that the quality of human resources and internal control system have a positive effect on the quality of local government financial statements. Subsequent research is expected to use populations at different sites in order that the results can be compared with previous researchers. Further research is also expected to consider other variables beyond this study.

Keywords: Quality of human resources, internal control system, quality of local government financial report.
} 
Ni Nyoman Trisnawati dan Dewa Nyoman Wiratmaja. Pengaruh ...

\section{PENDAHULUAN}

Peraturan Pemerintah mengenai pengelolaan keuangan daerah mengharuskan agar semua keuangan daerah diatur secara tertib, transparan, ekonomis, bertanggungjawab, taat pada peraturan yang berlaku, efektif dan efisien. Reformasi dalam hal pengelolaan keuangan ditandai dengan terbitnya UndangUndang Nomor 17 Tahun 2003 tentang Keuangan Negara. Dalam UndangUndang Nomor 17 Tahun 2003 tersebut mengharuskan Anggaran Pendapatan dan Belanja Negara (APBN) atau Anggaran Pendapatan Belanja Daerah (APBD) harus dibuat berdasarkan peraturan yang berlaku dimana sekarang ini yang berlaku di Indonesia adalah PP Nomor 71 Tahun 2010 tentang Standar Akuntansi Pemerintah

PP Nomor 71 Tahun 2010 ini terbit untuk menggantikan PP Nomor 24 Tahun 2005 dimana perubahan dalam kedua peraturan ini dapat dilihat dari sisi penyajian laporan keuangan. Dalam PP Nomor 24 Tahun 2005 Pemerintah Daerah hanya menyajikan empat (4) laporan keuangan yang terdiri dari Laporan Realisasi Anggaran, Neraca, Laporan Arus Kas dan Catatan atas Laporan Keuangan (CaLK), sedangkan dalam PP Nomor 71 Tahun 2010 Pemerintah Daerah diwajibkan membuat tujuh (7) laporan keuangan yang terdiri dari Laporan Realisasi Anggaran, Laporan Perubahan Saldo Anggaran Lebih (SAL), Neraca, Laporan Operasional (LO), Laporan Arus Kas, Laporan Perubahan Ekuitas dan Catatan atas Laporan Keuangan. Perbedaan yang lain antara PP Nomor 24 Tahun 2005 dengan PP Nomor 71 Tahun 2010 terletak pada basisnya dimana PP Nomor 24 Tahun 2005 menggunakan basis kas menuju akrual sedangkan PP Nomor 71 
Tahun 2010 menggunakan basis akrual. Adanya perubahan pada peraturan yang berlaku sedikit tidaknya akan berdapak pada satuan kerja kepemerintahan (Pramana, 2016). Ada sedikit bukti tentang manfaat yang terkait dengan penerapan akuntansi berbasis akrual, sementara akademisi telah meremehkan pentingnya akuntansi akrual di sektor publik (Lapsley, 2009). Namun, banyak penelitian telah menganjurkan superioritas akuntansi berbasis akrual dibandingkan dengan akuntansi berbasis kas sehingga alasan mengapa banyak organisasi sektor publik internasional telah mengadopsi atau sedang dalam proses menerapkan prinsip akuntansi akrual (Connolly and Hyndman, 2006). Akuntansi akrual membantu memperbaiki keputusan manajer, memberikan biaya dan aktivitas layanan yang lebih transparan dan meningkatkan akuntabilitas manajer (Karbasi et al., 2010).

Terbitnya Peraturan Pemerintah Nomor 71 Tahun 2010 ini menuntut pemerintah daerah untuk memenuhi kriteria karakteristik kualitatif laporan keuangan yaitu relevan, andal, dapat dibandingkan dan dapat dipahami. Peraturan pemerintah yang berlaku sekarang ini yaitu PP No. 71 Tahun 2010 mengadopsi karakteristik kualitatif primer yang terdapat pada Statement of Financial Accounting Concepts (SFAC) No. 2. Perbedaan keduanya terletak pada penekanannya saja, pada PP No. 71 Tahun 2010 hanya menekankan pada empat (4) persyaratan saja.

Laporan keuangan dapat dikatakan relevan apabila informasi yang termuat didalam laporan keuangan tersebut dapat memengaruhi keputusan pengguna laporan keuangan. Dengan adanya informasi dari laporan keuangan ini juga 
diharapkan dapat memberi prediksi di masa yang akan datang dan dapat mengevaluasi peristiwa masa lalu atau masa kini. Informasi yang terkandung dalam laporan keuangan haruslah disajikan tepat waktu sehingga dapat berguna bagi pengambilan keputusan dan informasi yang disajikan harus lengkap dan terperinci. Laporan keuangan dikatakan andal apabila innformasi dalam laporan keuangan harus bebas dari kesalahan material, menyajikan setiap informasi secara jujur dan dapat diverifikasi.Informasi pada laporan keuangan yang disajikan harus diarahkan pada kepentingan umum dan tidak berpihak kepada pihak tertentu. Laporan keuangan dapat dikatakan dapat dibandingkan jika informasi yang disajikan dalam laporan keuangan tersebut dapat dibandingakan dengan laporan keuangan periode sebelumnya. Laporan keuangan dikatakan dapat dipahami jika informasi yang terdpar dalam laporan keuangan bermanfaat jika dapat dipahami oleh semua pihak yang menggunakan atau memerlukan laporan keuangan.

Pemerintah dituntut untuk dapat memenuhi semua kriteria tersebut agar tidak menimbulkan kelemahan dalam hal administrasi, ketidakefsienan dan ketidakefektifan. Informasi dapat dikatakan berguna apabila terjadi perubahan data dalam konteks tertentu (Lillrank, 2003). Fakta yang terjadi di lapangan mengenai fenomena pelaporan keuangan pemerintah di Indonesia sangat menarik untuk diteliti, dimana laporan keuangan yang disajikan oleh pemerintah tidak dapat menggambarkan keseluruhan dari akuntabilitas dari pemerintah bersangkutan (Steccolini, 2002). Dalam pengambilan keputusan, laporan keuangan pemerintah sangat diperlukan akuntabilitasnya (Ryan et al, 2002). Pemerintah daerah seharusnya memiliki kewajiban untuk mempublikasikan 
laporan keuangannya untuk memberikan informasi yang bermanfaat bagi penggunanya, namun sedikit sekali pemerintah daerah yang melakukan publikasi tersebut.

Isthika, dkk (2014) menyebutkan bahwa laporan keuangan adalah media bagi sebuah entitas dalam hal ini pemrintah daerah untuk memberikan pertanggungjawaban kinerja keuangannya kepada publik. Pemerintah dituntut untuk dapat menyajikan laporan keuangan yang berkualitas agar dapat berguna bagi penggunanya. Laporan keuangan yang berkualitas merupakan tujuan dari organisasi sektor publik sebagi bentuk pertagungjawaban atas wewenang yang telah diberikan. Laporan keuangan yang berkualitas juga dapat tercermin dari pendapat yang diberikan oleh Badan Pemeriksa Keuangan (BPK). Informasi yang termuat dalam laporan keuangan pemerintah haruslah berguna yaitu dapat memberikan dukungan dalam hal pengambilan keputusan serta dapat meningkatkan pemahaman oleh para pengguna laporan keuangan (Huang et al., 1999 dalam Xu et al., 2003).

Peningkatan kualitas LKPD melalui implementasi Peraturan Pemerintah Nomor 60 Tahun 2008 dirasa sudah memberikan hasil yang cukup efektif. Opini yang diberikan oleh BPK merupakan cerminan bagi kualitas laporan keuangan yang dihasilkan oleh suatu instansi pemerintah. Hasil dari pemeriksaan semester 1 tahun 2017 dimana BPK seharusnya memeriksa 542 laporan keuangan tetapi hanya memeriksa 537 laporan keuangan. Hal tersebut dikarenakan 5 pemerintah daerah terlambat mengumpulkan laporan keuangan, dimana yang terlambat adalah Pemerintah Kabupaten (Pemkab) Aceh Singkil, Aceh Tenggara, Pidie, Pidie Jaya, 
dan Pemerintah Kota (Pemkot) Lhokseumawe di wilayah Provinsi Aceh. Dari LKPD tersebut BPK memberikan 375 opini Wajar Tanpa Pengecualian (WTP), 139 opini Wajar Dengan Pengecualian (WDP), dan 23 opini Tidak Memberikan Pendapat (TMP). Hasil dari opini yang didapat oleh pemkab di Indonesia telah melebihi target dari kinerja keuangan. Pada tahun 2015 hasil pemeriksaan atas laporan BPK sebanyak 313 dari 524 laporan keuangan memeroleh opini WTP dan pada Tahun 2016 sebanyak 375 dari 537 laporan keuangan memeroleh WTP. Dari hasil tersebut dapat membuktikan bahwa adanya peninggatan dalam jumlah penelaian WTP dari BPK dari Tahun 2015 ke Tahun 2016 begitupula dengan opini dari opini Tidak Wajar (TW) atau TMP menjadi opini WDP sebanyak 15 LKPD. Daftar Opini LKPD Tahun 2012-2016 (www.bpk.go.id).

Hasil pemeriksaan BPK atas 537 LKPD mengungkapkan bahwa terjadi kelemahan pada SPI yaitu sebanyak 6.053 yang diantaranya permasalahan kelemahan pada system pengendalian akuntansi dan pelaporan sebanyak 2.156 permasalahan, permasalahan kelemahan system pengendalian pelaksanaan anggaran pendapatan dan belanja sebanyak 2.657 dan permasalahan kelemahan struktur pengendalian intern sebanyak 2.340 kelemahan. Kesalahan seperti itu secara umum dapat terjadi karena kurangnya pertanggungjawaban dari pejabat yang berwenang dalam mengoptimalkan pembinaan pemahaman akuntansi dan belum maksimalnya dalam pengawasan dan pengendalian.

Audit oleh Badan Pemeriksa Keuangan (BPK) sangat diperlukan dalam hal peningkatan akuntabilitas dan transparansi laporan keuangan pemerintah pusat maupun daerah. Pada Ikhtisar Hasil Pemeriksaan (IHP) Semester I tahun 
2017 opini BPK untuk laporan keuangan pemerintah daerah (LKPD) Kabupaten Gianyar Tahun 2016 adalah Wajar Tanpa Pengecualian (WTP) (www.bpk.go.id). Opini WTP menunjukkan bahwa laporan keuangan yang disusun oleh suatu instansi telah disajikan secara wajar, tidak terdapat kesalahan material dan sudah sesuai dengan standar yang berlaku. Opini yang diberikan oleh BPK yaitu WTP kepada Pemerintah Kabupaten Gianyar menunjukkan bahwa dalam menyusun laporan keuangan Pemerintah Kabupaten Gianyar telah menyusunya sesuai dengan peraturan yang berlaku dan perundang-undangan yang berlaku serta disajikan secara andal dan tepat waktu. Namun bersamaan dengan hal tersebut BPK masih menemukan adanya kelemahan sistem pengendalian intern dalam penyusunan laporan keuangan yaitu dalam pemungutan, penyetoran dan pelaporan pajak, penatausahaan aset tetap pemerintah Kabupaten Gianyar yang belum tertib.

Masih rendahnya kualitas LKPD disebabkan oleh kualitas SDM yang kurang memadai (Subrata, 2017). Kualitas SDM adalah elemen yang sangat penting jadi sebab itu kualitas SDM harus selalu dipastikan pengelolaannya dilakukan dengan baik agar dapat memberikan kontribusi yang optimal dalam upaya pencapaian tujuan organisasi (Afrianti, 2011). Kuranganya kualitas SDM ini dapat disebabkan karena dalam melaksanakan pertanggungjwaban anggaran, banyak staf keuangan dalam OPD yang bukan berlatar belakang pendidikan akuntansi, hal tersebut juga dapat mempengaruhi kualitas dari laporan keuangan pemerintah daerah.

Faktor yang lain yang dapat memengaruhi kualitas laporan keuangan pemerintah daerah adalah sistem pengendalian intern (SPI), dimana SPI ini 
Ni Nyoman Trisnawati dan Dewa Nyoman Wiratmaja. Pengaruh ...

merupakan salah satu elemen yang penting dalam memberikan akuntabilitas untuk memantau dan mengendalikan suatu organisasi (Jones, 2008). Sistem Pengendalian Intern merupakan tindakan yang dilakukan pada keuangan dan nonkeuangan untuk memastikan perlindungan atas aset, deteksi dan pencegahan penipuan, memenuhi persyaratan dan prosedur kebijakan internal control dan akurasi kelengkapan catatan (Abiola et al., 2013). Jika suatu entitas telah menetapkan pengendalian intern dengan baik maka semua operasi, sumber daya fisik, dan data akan dimonitor serta berada di bawah kendali, tujuan akan tercapai, risiko menjadi kecil, dan informasi yang dihasilkan akan lebih berkualitas (Weygandt et al., 2005). Tidak tercapianya pengendalian intern yang baik akan menyebabkan kualitas laporan keuangan yang dihasilkan perintah daerah buruk (Suwanda, 2015).

Berdasarkan latar belakang yang telah dijabarkan tersebut peneliti ingin membuktikan pengaruh kedua faktor yaitu kualitas sumber daya manusia (SDM), dan sistem pengendalian intern (SPI) terhadap kualitas laporan keuangan pemerintah daerah Kabupaten Gianyar. Responden dari penelitian ini adalah Organisasi Perangkat Daerah (OPD) Kabupaten Gianyar yang berpatisapasi dalam pembuatan laporan keuangan sehingga dirasa cukup kuat sebagai sampel penelitian. Berdasarkan fenomena tersebut maka peneliti tertarik untuk menyusun penelitian yang berjudul "Pengaruh Kualitas Sumber Daya Manusia dan Sistem Pengendalian Intern Pada Kualitas Laporan Keuangan Daerah”. Berdasarkan latar belakang masalah tersebut, maka rumusan masalah penelitian ini diantaranya (1) Bagaimana pengaruh kualitas Sumber Daya Manusia (SDM) pada kulitas laporan 
keuangan pemerintah daerah? (2) Bagaimana pengaruh Sistem Pengendalian Intern (SPI) terhadap kualitas laporan keuangan pemerintah daerah?. Berdasarkan rumusan masalah tersebut maka yang menjadi tujuan penelitian ini adalah sebagai berikut (1) Untuk mengetahui pengaruh kualitas sumber Daya Manusia (SDM) pada kualitas laporan keuangan pemerintah daerah. (2) Untuk mengetahui pengaruh Sistem Pengendalian Internal (SPI) pada kualitas laporan keuangan pemerintah daerah.

Hasil dari penelitian ini diharapkan akan memberikan manfaat secara teoretis maupun praktis bagi semua pihak yang mempunyai kaitan dengan penelitian ini, antara lain (1) Manfaat Teoretis hasil penelitian ini diharapkan akan dapat menambah wawasan bagi para akademisi dan juga pemerintah, penelitian ini juga diharapkan mampu memberikan wawasan mengenai pengaruh kualitas SDM dan SPI pada kualitas laporan keuangan Pemerintah Kabupaten Gianyar. Penelitian ini juga dapat diharapkan menjadi referensi bagi pihak-pihak yang akan melakukan penelitian lebih mendalam mengenai topik penelitian ini. Penelitian ini diharapkan dapat menyumbangkan bukti empiris mengenai teory agency dalam menjelaskan pengaruh kualitas SDM dan SPI pada kualitas laporan keuangan pemerintah daerah. (2) Manfaat Praktis hasil dari penelitian ini diharapkan dapat memberikan pemahaman, gambaran dan wawasan mengenai pengaruh kualitas SDM dan SPI terhadap kualitas laporan keuangan pemerintah daerah khususnya di OPD Kabupaten Gianyar. Selain itu, penelitian ini juga diharapkan dapat memberikan kontribusi dalam memperkuat bukti empiris dan dijadikan perbandingan, pengembangan dan penyempurnaan dari penelitian- 
penelitian yang telah dilakukan oleh peneliti-peneliti sebelumnya.

Penelitian ini didasarkan atas teori keagenan yang mengaitkan hubungan diantara pemerintah sebagai agen dan rakyat sebagai principal dimana pemerintah sebagai pemegang amanah dari rakyat berkewajiban agar memberikan pertanggungjawaban, menyajikan dan melaporkan serta mengungkapkan semua kegiatan yang dilakukan oleh pemerintah kepada rakyat selaku pihak pemberi amanah (Jensen and Meckling, 1976). Teori keagenan sudah dipergunakan pada sektor publik baik itu di pemerintahan pusat maupun daerah.

Berdasarkan paparan diatas dapat dibuat hipotesis penelitian sebagai berikut.

$\mathrm{H}_{1}$ : Kualitas sumber daya manusia berpengaruh positif pada kualitas laporan keuangan pemerintah daerah.

$\mathrm{H}_{2}$ : Sistem Pengendalian Intern berpengaruh positif pada kualitas laporan keuangan pemerintah daerah.

\section{METODE PENELITIAN}

Penelitian ini menggunakan pendekatan kuantitatif yang berbentuk asosiatif. Penelitian ini dilakukan di Kabupaten Gianyar pada Organisasi Perangkat Daerah (OPD) Kabupaten Gianyar. Pemilihan lokasi penelitian ini berdasarkan penilaian BPK Laporan Keuangan Pemerintah Daerah (LKPD) Kabupaten Gianyar yang tidak selalu Wajar Tanpa Pengecualian (WTP). Objek dari penelitian ini adalah kualitas laporan keuangan pemerintah daerah Kabupaten Gianyar. Objek penelitian ini dipilih karena pentingnya kualitas dari laporan keuangan yang akan disajikan oleh pemerintah daerah untuk menunjukkan kepada masayarakat bahwa pemerintah telah menjalankan amanah dari rakyat dengan baik. Dalam penelitian ini menggunakan dua variabel yang diantaranya (1) Variabel dependen atau 
variable terikat merupakan variable yang dipengaruhi atau menjadi akibat karena adanya variable independen atau variable bebas (Sugiyono, 2013:59). Variabel dependen dalam penelitian ini adalah kualitas informasi laporan keuangan pemerintah daerah perubahan, (2) Variabel independen atau variable bebas merupakan variable yang memengaruhi atau yang menjadi sebab atau timbulnya variable dependen atau variable terikat (Sugiyono, 2013:59). Variabel independen dalam penelitian ini antara lain kualitas sumber daya manusia (SDM), dan sistem pengendalian intern (SPI).

Populasi dari penelitian ini adalah 33 OPD di Kabupaten Gianyar yang berbentuk dinas, badan dan kantor kecamatan. Metode penentuan sampel yang digunakan dalam penelitian ini adalah nonprobability sampling dengan teknik purposive sampling, yaitu metode penentuan sampel dengan pertimbangan tertentu. Tujuan penggunaan purposive sampling agar mendapatkan sampel yang representatif yang sesuai dengan kriteria yang ditentukan. Sumber data yang digunakan dalam penelitian ini adalah data primer. Dalam penelitian ini menggunakan jenis instrument yaitu kuesioner. Data dikumpulkan dengan cara menyebar secara langsung kuesioner kepada responden dan dijemput kembali selama 14 hari.

Teknik analisis data yang dipergunakan dalam penelitian ini adalah teknik analisis linear berganda. Adapun model regresi linear berganda dengan menggunakan persamaan sebagai berikut.

$\mathrm{Y}=\mathrm{a}+\mathrm{b}_{1} \mathrm{X}_{1}+\mathrm{b}_{2} \mathrm{X}_{2}+\mathrm{e}$ 
Keterangan:

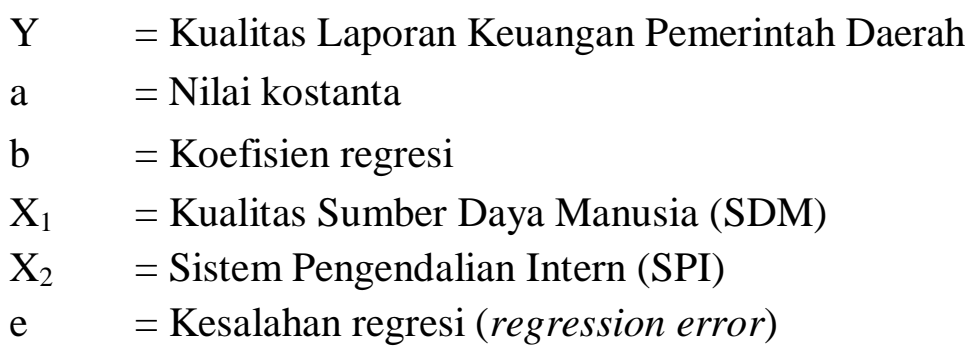

\section{HASIL DAN PEMBAHASAN}

Populasi penelitian ini berjumlah 33 OPD yang ada di Kabupaten Gianyar yang berbentuk dinas, badan dan kantor kecamatan. Responden penelitian pada masingmasing OPD berjumlah 3 orang yang terdiri dari kepala sub bagian keuangan dan stafnya. Adapun dipilihnya kepala sub bagian keuangan dan staf karena merekalah yang berhubungan langsung dengan pembuatan laporan keuangan di masingmasing OPD tempat mereka bertugas.

Tabel 1.

Ringkasan Pengiriman dan Pengembalian Kuesioner

\begin{tabular}{lcc}
\hline \multicolumn{1}{c}{ Kuesioner } & Jumlah & Persentase (\%) \\
\hline Kuesioner dikirim & 99 & 100 \\
Kuesioner kembali & 95 & 95,95 \\
Kuesioner tidak kembali & 4 & 4,04 \\
Kuesioner yang digunakan & 95 & 95,95 \\
\hline Sumber: Data diolah, 2018 & &
\end{tabular}

Ringkasan pengiriman dan pengembalian kuesioner dapat diketahui jumlah kuesioner yang disebar sebanyak 99 kuesioner dan kuesioner yang kembali sebanyak 4 kuesioner. Dalam kuesioner yang kembali tidak ada kuesioner yang gugur atau tidak digunakan sehingga banyak kuesioner yang digunakan adalah sebanyak 95 kuesioner. 
ISSN: 2302-8556

E-Jurnal Akuntansi Universitas Udayana Vol.24.1.Juli (2018): 768-792

Tabel 2.

Hasil Statistik Deskriptif

\begin{tabular}{lccccc}
\hline \multicolumn{1}{c}{ Variabel } & N & Minimum & Maximum & Mean & $\begin{array}{c}\text { Standar } \\
\text { Deviasi }\end{array}$ \\
\hline $\begin{array}{l}\text { Kualitas Laporan Keuangan } \\
\text { Pemerintah Daerah }\end{array}$ & 95 & 25 & 40 & 32,77 & 3,761 \\
$\begin{array}{l}\text { Kualitas Sumber Daya } \\
\text { Manusia }\end{array}$ & 95 & 27 & 40 & 33,88 & 3,387 \\
Sistem Pengendalian Intern & 95 & 26 & 45 & 38,09 & 3,425 \\
Valid N (listwise) & 95 & & & & \\
\hline
\end{tabular}

Sumber: Data diolah, 2018

Hasil statistik deskriptif diatas dapat disimpulkan bahwa jumlah pengamatan $(\mathrm{N})$ adalah sebanyak 95. Skor minimum menunjukkan nilai terendah, skor maximum menunjukkan nilai tertinggi sedangkan rata-rata ditunjukkan dengan mean. Variabel kualitas laporan keuangan pemerintah daerah nilai minimumnya sebesar 25 dan nilai maksimumnya sebesar 40 dengan nilai rata-rata sebesar 32,77. Variabel kualitas SDM nilai minimumnya sebesar 27 dan nilai maksimumnya sebesar 40 dengan nilai rata-rata 33,88 . Variabel SPI nilai minimumnya sebesar 26 dan nilai maksimumnya sebesar 45 dengan rata-rata sebesar 38,09.

Pengujian instrumen terdiri dari uji validitas dan uji reliabilitas. Pengujian dilakukan dengan menyebarkan kuesioner uji coba pada 30 responden. Responden yang digunakan ialah mahasiswa jurusan akuntansi angkatan 2014, Fakultas Ekonomi dan Bisnis, Universitas Udayana. Suatu kuesioner dikatakan valid apabila pernyataan pada kuesioner mampu untuk mengungkapkan sesuatu yang akan diukur oleh kuesioner tersebut. Umar (2004:127) menyebutkan bahwa 
validitas dalam penelitian dijelaskan sebagai suatu derajat ketepatan alat ukur penelitian tentang inti atau arti sebenarnya yang diukur.

Penelitian ini menggunakan korelasi pearson correlation dengan bantuan program Statistical Package for Social Science (SPSS) untuk membantu dalam pengukuran validitas instrument. Uji validitas dilakukan melalui cara melihat nilai signifikansi pada hasil analais yang digunakan dimana yang digunakan adalah analisis korelasi bivariate pada kolom Corelations (Ghozali, 2013:55). Agar kuesioner memenuhi tingkat validitas, semua butir yang ada pada kuesioner harus nilai korelasi antar suatu butir dengan skor total tersebut positif dan besarnya lebih dari 0,30 (Sugiyono, 2014:178).

Berdasarkan hasil koefisien korelasi pada instrumen tersebut seluruh variabel memiliki nilai korelasi dengan skor seluruh item, pertanyaan lebih besar dari 0,30. Hal tersebut menunjukkan bahwa semua pertanyaan dalam instrument tersebut valid. Dalam suatu penelitian, suatu instrument dapat dinyataan reliabel jika nilai dalam cronbach's alpha melebihi dari 0,70 (Ghozali, 2013:47). Jika nilai koefisien (alpha) melebihi dari nilai Alpha Cronbach $(0,70)$ maka butir pertanyaan variabel dalam kuesioner tersebut reliabel. Sedangkan jika koefisien (alpha) lebih kecil dari Alpha Cronbach $(0,70)$ maka butir pertanyaan variabel dalam kuesioner tersebut tidak reliabel. Hasil uji reliabilitas disajikan dalam Tabel 3. Hasil uji reliabilitas yang ditunjukkan pada Tabel 3 memiliki arto bahwa semua instrument dalam penelitian ini memiliki Cronbach's Alpha lebih dari 0,70. Hai ini menunjukkan bahwa semua instrument dalam penelitian ini reliable oleh karena itu dapat digunakan untuk melaksanakan penelitian. 
Tabel 3.

Hasil Uji Reliabilitas

\begin{tabular}{lcc}
\hline \multicolumn{1}{c}{ Variabel } & $\begin{array}{c}\text { Koefisien Alpha } \\
\text { Cronbach }\end{array}$ & Keterangan \\
\hline $\begin{array}{l}\text { Kualitas Laporan Keuangan Pemerintah } \\
\text { Daerah }\end{array}$ & 0,762 & Reliabel \\
Kualitas Sumber Daya Manusia & 0,803 & Reliabel \\
Sistem Pengendalian Intern & 0,710 & Reliabel \\
\hline
\end{tabular}

Sumber: Data diolah, 2018

Uji asumsi klasik digunakan untuk memastikan bahwa hasil yang diperoleh memiliki asumsi dasar di dalam analisis regresi. Hasil uji asumsi klasik yang digunakan dalam penelitian ini adalah uji normalitas, uji multikoleniaritas dan uji heteroskedastisitas.

Uji normalitas digunakan untuk menguji apakah dalam model regresi, variabel pengganggu atau residual memiliki distribusi normal (Ghozali, 2013:160). Penentuan normal atau tidaknya distribusi data dapat dilakukan pengujian dengan menggunakan statistik Kolmogorov-Smirnov. Kriteria dalam model penelitian ini untuk uji normalitasnya adalah menggunakan perbandingan antara tingkat signifikan dengan tingkat alpha yang digunakan, dimana data tersebut dikatakan berdistribusi normal bila sig $>$ alpha $=0,05$. Hasil uji normalitas disajikan pada Tabel 4 berikut.

Tabel 4.

Hasil Uji Normalitas

Keterangan

$\mathrm{N}$

Kolmogorov-Smirnov $Z$ Asymp.Sig. (2-tailed)

Sumber: Data diolah, 2018
Unstandardized Predicted Value

0,561

0,921 
Ni Nyoman Trisnawati dan Dewa Nyoman Wiratmaja. Pengaruh ...

Tabel 4 menunjukkan bahwa nilai signifikan dari hasil uji normalitas pada persamaan tersebut sebesar 0,921 . Jadi, dapat disimpulkan bahwa model regresi memenuhi uji normalitas karena nilai Asymp. Sig. lebih besar dari 0,05.

Uji multikoleniaritas bertujuan untuk menguji apakah pada model regresi ditemukan adanya korelasi antar variabel bebas. Adanya multikoleniaritas dapat diketahui jika nilai tolerance $\leq 0,10$ atau sama dengan VIF $\geq 10$. Tabel 5 berikut menunjukkan hasil uji multikoleniaritas.

Tabel 5.

Hasil Uji Multikoleniaritas

\begin{tabular}{lcc}
\hline \multicolumn{1}{c}{ Variabel } & Tolerance & VIF \\
\hline Kualitas Sumber Daya Manusia & 1,000 & 1,000 \\
Sistem Pengendalian Intern & 1,000 & 1,000 \\
\hline Sumber: Data diolah, 2018 & &
\end{tabular}

Hasil uji multikoleniaritas menunjukkan bahwa nilai tolerance lebih besar dari 10 persen dan nilai VIF lebih kecil dari 10. Hasil ini menunjukkan bahwa pada model regresi tidak terjadi gejala-gejala multikolinearitas.

Uji Heterokedastisitas

Uji heterokedastisitas bertujuan untuk menguji apakah model regresi terjadi ketidaksamaan variance dari residual satu pengamatan ke pengamatan lainnya. Tabel 6 menunjukkan hasil uji heterokedastisitas dengan menggunakan uji Glejser.

Tabel 6.

Hasil Uji Heterokedastisitas

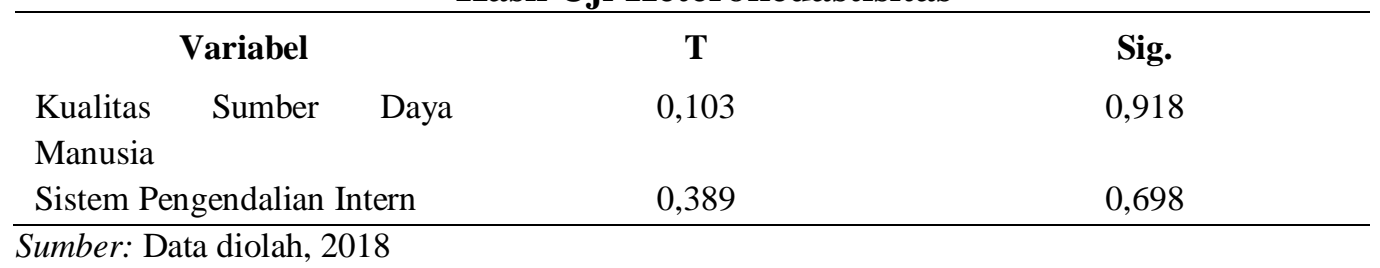


Hasil uji heteroskedastisitas diketahui nilai signifikansi dari masing-masing variabel pada model regresi nilainya lebih dari 0,05 . Hasil tersebut dapat menggambarkan bahwa model pada regresi penelitian ini tidak mengandung heteroskedastisitas.

Analisis regresi linear berganda digunakan untuk mengetahui pengaruh kualitas sumber daya manusia, sistem pengendalian intern dan kualitas laporan keuangan pemerintah daerah. Hasil analisis regresi linear berganda dapat dilihat pada Tabel 7.

Tabel 7.

Hasil Uji Analisis Regresi Linear Berganda

\begin{tabular}{lcc}
\hline \multicolumn{1}{c}{ Keterangan } & F & Signifikansi \\
\hline Regression & 15,674 & 0,000 \\
\multicolumn{1}{c}{ Keterangan } & Nilai Beta & Signifikansi \\
(Constant) & 8,156 & 0,068 \\
Kualitas SDM & 0,295 & 0,001 \\
Sistem Pengendalian Intern & 0,384 & 0,000 \\
Adjusted $R$ Square & & 0,238 \\
\hline Sumber $:$ Data diolah, 2018 & &
\end{tabular}

Sumber : Data diolah, 2018

Berdasarkan Tabel 7 maka persamaan analisis regresi linear berganda adalah sebagai berikut .

$\mathrm{Y}=\mathrm{a}+\mathrm{b}_{1} \mathrm{X}_{1}+\mathrm{b}_{2} \mathrm{X}_{2}+\mathrm{e}$

$\mathrm{Y}=8,156+0,295 \mathrm{X}_{1}+0,384 \mathrm{X}_{2}+\mathrm{e}$

Keterangan :

$\mathrm{Y}=$ Kualitas laporan keuangan pemerintah daerah

$\mathrm{X}_{1}=$ Kualitas SDM

$\mathrm{X}_{2}=$ Sistem pengendalian intern 
Persamaan tersebut menunjukkan bahwa nilai konstanta sebesar 8,156 dengan nilai positif. Nilai tersebut menunjukkan bahwa variabel kualitas LKPD akan bernilai 8,156 jika masing-masing variabel kualitas sumber daya manusia dan sistem pengendalian intern bernilai nol.

Variabel kualitas sumber daya manusia memiliki nilai koefisien regresi sebesar 0,295. Hal tersebut menunjukkan bahwa setiap kenaikan $1 \%$ variabel kualitas sumber daya manusia dengan asumsi variabel lain tetap maka akan meningkatkan variabel kualitas laporan keuangan pemerintah daerah sebesar $29,5 \%$.

Nilai koefisien regresi variabel sistem pengendalian intern pada penelitian ini adalah sebesar 0,384. Nilai tersebut menunjukkan bahwa jika setiap kenaikan $1 \%$ pada variabel sistem pengndalian intern dengan asumsi variabel lain tetap maka akan meningkatkan variabel kualitas laporan keuangan pemerintah daerah sebesar 38,4\%. Uji $\mathrm{F}$ digunakan untuk menguji apakah variabel bebas yang digunakan dalam penelitian ini secara simultan memiliki pengaruh terhadap variabel terikat. Apabila tingkat signifikansi $\mathrm{F} \leq \alpha=0,05$ maka hubungan antar variabel bebas signifikan memengaruhi kualitas laporan keuangan pemrintah daerah.

Tabel 7 diketahui nilai signifikansi uji F yaitu sebesar 0,000 yang berarti lebih kecil dari 0,05. Hal ini berarti bahwa model yang digunakan pada penelitian ini adalah layak. Hasil ini memberikan makna bahwa kedua variabel independen mampu memprediksi atau menjelaskan variabel dependen. 
Koefisien determinasi $\left(\mathrm{R}^{2}\right)$ bertujuan untuk mengukur seberapa jauh kemampuan model dalam menerangkan variabel dependen. Dari Tabel 7 diketahui hasil dari perhitungan yang dilakukan nilai Adjusted $\mathrm{R}^{2}$ adalah 0,238 . Hasil tersebut berarti bahwa 23,8 persen variasi variabel kualitas laporan keuangan pemerintah daerah mampu dijelaskan oleh variabel kualitas SDM dan SPI, sedangkan sisanya sebesar 76,2 persen dijelaskan oleh faktor-faktor lain yang tidak dijelaskan dalam model.

Uji $\mathrm{t}$ dipergunakan dalam menguji suatu hipotesis dimana hipotesis tersebut diuji untuk mengetahui bahwa variabel bebas yang digunakan secara parsial berpengaruh pada variabel terikat. Hasil pengujian pengaruh kualitas SDM dan SPI pada kualitas laporan keuangan pemerintah daerah, berdasarkan hasil perhitungan diketahui bahwa nilai t hitung pada variabel kualitas sumber daya manusia adalah sebesar 3,599 dengan tingkat signifikansi sebesar 0,001 niali ini lebih kecil dari batas signifikansi yaitu sebesar 0,05. Berdasarkan hasil perhitungan tersebut sehingga pengujian hipotesis penelitian pertama yang menyatakan kualitas sumber daya manusia berpengaruh positif pada kualitas laporan keuangan pemerintah daerah diterima. Nilai t hitung pada variabel sistem pengendalian intern adalah sebesar 4,213 dengan tingkat signifikansi sebesar 0,000 nilai ini lebih kecil dari batas signifikansi yaitu sebesar 0,05. Berdasarkan hasil perhitungan dtersebut sehingga hopotesis penelitian kedua dari penelitian ini yang menyatakan sistem pengendalian intern berpengaruh positif pada kualitas laporan keuangan pemerintah daerah diterima. 
Pembahasan untuk masing-masing hasil uji hipotesis dapat dijelaskan sebagai berikut. Hipotesis pertama $\left(\mathrm{H}_{1}\right)$ dalam penelitian ini menyatakan kualitas sumber daya manusia berpengaruh positif pada kualitas laporan keuangan pemerintah daerah. Berdasarkan hasil pengujian hipotesis pertama dari penelitian ini menyatakan kualitas sumber daya manusia berpengaruh signifikan dan positif pada kualitas laporan keuangan pemerintah daerah, hal tersebut berarti semakin baik kualitas SDM maka akan meningkat pula kualitas laporan keuangan pemerintah daerah. Penelitian ini akan memberikan tambahan bukti empiris bahwa kualitas SDM berpengaruh pada kualitas laporan keuangan pemerintah daerah.

Berdasarkan dari data yang diperoleh, tingkat pendidikan pegawai sub bagian keuangan rata-rata memiliki tingkat pendidikan S1 yaitu sebanyak 73 pegawai dari 95 pegawai. Dengan tingakat pendidikan tersebut pegawai sub bagian keuangan sudah dirasa cukup memadai untuk menjalankan tugas sebagai pengelola keuangan dengan bekal yang telah dimiliki. Dari hasil tabulasi data penelitian ini untuk variabel kualitas SDM pertanyaan nomor dua dan empat memeroleh nilai paling sedikit diantara pertanyaan-pertanyaan yang lain. Hal tersebut membuktikan bahwa pegawai sub bagian keuangan pada OPD tempatnya bekerja kurang melakukan pelatihan untuk menunjang kemampuan mereka dalam menyusun laporan keuangan.

Hasil yang diperoleh dari penelitian ini sejalan dengan penelitian terdahulu yang dilakukan oleh Evacahyani (2016), Kusuma (2016), dan Puspitawati (2016) yang menyatakan kompetensi SDM berpengaruh positif dan signifikan pada 
kualitas laporan keuangan pemerintah daerah. Namun hasil penelitian ini tidak sejalan dengan penelitian yang dilakukan oleh Zuliarti (2012) yang menyatakan SDM tidak berpengaruh pada laporan keuangan. Penelitian yang dilakukan oleh Zuliarti (2012) tersebut dilakukan di Pemerintah Kabupaten Kudus. Perbedaan yang diperoleh dari hasil penelitian ini dapat disebabkan oleh adanya perbedaan budaya antara lokasi penelitian ini dan lokasi penelitian yang dilakukan oleh Zuliarti (2012).

Hipotesis kedua $\left(\mathrm{H}_{2}\right)$ dari penelitian ini menyatakan bahwa SPI berpengaruh positif pada kualitas laporan keuangan pemerintah daerah berdasarkan uji hipotesis yang dilakukan menunjukkan bahwa SPI berpengaruh positif pada kualitas laporan keuangan pemerintah daerah. Hal tersebut menunjukkan semakin baik sistem pengendalian intern maka akan semakin baik pula kualitas laporan keuangan yang dihasilkan oleh OPD di Kabupaten Gianyar. Hasil tabulasi data penelitian ini untuk variabel sistem pengendalian intern diketahui bahwa pertanyaa untuk kuesioner nomor tujuh dan enam mendapat nilai paling sedikit. Hasil tersebut mebuktikan bahwa OPD di Kabupaten Gianyar belum sepenuhnya menerapkan sistem informasi dengan baik dan belum melakukan pemisahan tugas dengan memadai, hal tersebut dapat memengaruhi kualitas laporan keuangan yang di hasilkan oleh OPD di Kabupaten Gianyar.

Hasil penelitian dari penelitian ini mendukung penelitian yang dilakukan oleh Yosefrinaldi (2013) yang dimana penelitian tersebut menyebutkan bahwa SPI pemerintah berpengaruh positif terhadap pada laporan keuangan pemerintah daerah. Kemudian, Yudianta \& Erawati (2012) dengan hasil penelitiannya bahwa 
pengendalian intern akuntansi berpengaruh positif terhadap kualitas informasi akuntansi. Zuliarti (2012), pengendalian intern akuntansi berpengaruh positif signifikan terhadap keterandalan pelaporan keuangan pemerintah daerah.

\section{SIMPULAN}

Bagi Pemerintah Daerah Kabupaten Gianyar, dari hasil penelitian ini dapat menjadi bahan untuk mengevaluasi kinerja OPD Kabupaten Gianyar dalam hal penyusunan laporan keuangan agar dapat tercapainya kualitas laporan yang sesuai dengan standar yang berlaku di Indonesia. Hal tersebut dapat tercapai dengan cara peningkatan dalam hal kualitas SDM melalui pelatihan-pelatihan dengan materi yang sesuai dengan peraturan dalam penyusunan laporan keuangan dan meningkatkan sistem pengendalian intern di dalam OPD yang bersangkutan. Sehingga kualitas laporan keuangan dapat sesuai peraturan yang berlaku dimana saat ini yang berlaku adalah PP Nomor 71 Tahun 2010. Implikasi teori keagenan pada penelitian ini yaitu dapat menjelaskan kewajiban pemerintah daerah sebagai suatu lembaga yang dapat dipercaya oleh masyarakat dalam menjalankan amanah yang diberikan oleh rakyat, dapat memberikan pelayanan yang baik kepada masyarakat, dan mampu membuat pertanggungjawaban keuangan yang diamanahkan kepada pemerintah, sehingga terpenuhi kesejahteraan masyarakat secara maksimal.

Penelitian ini menguji pengaruh kualitas SDM dan SPI pada kualitas laporan keuangan pemerintah daerah. Penelitian ini dilakukan pada 33 OPD Kabupaten Gianyar yang berbentuk dinas, badan dan kantor kecamatan. Berdasarkan hasil penelitian, maka kesimpulan dari penelitian ini adalah sebagai 
berikut, (1) Kualitas SDM berpengaruh positif pada kualitas laporan keuangan pemerintah daerah Kabupaten Gianyar. Artinya semakin baik kualitas SDM yang dimiliki oleh suatu OPD maka akan semakin baik pula kualitas laporan keuangan pemerintah daerah yang dihasilkan, (2) SPI berpengaruh berpengaruh positif pada kualitas laporan keuangan pemerintah daerah Kabupaten Gianyar. Hal tersebut membuktikan bahwa semakin baik sistem pengendalian intern yang dimiliki oaleh suatu OPD maka akan semakin baik pula kualitas laporan keuangan pemerintah daerah yang dihasilkan.

Berdasarkan hasil analisis dan simpulan, maka saran yang dapat disampaikan yaitu sebagai berikut, (1) Dalam rangka peningkatan kualitas laporan keuangan pemerintah daerah, sebaiknya OPD melakukan peningkatan pada kualitas SDM agar benar-benar memiliki kemampuan untuk menyusun laporan keuangan, (2) Pelatihan pada pegawai OPD disarankan agar dilaksanakan secara rutin agar pegawai yang ada pada OPD tersebut mampu menyajikan laporan keuangan yang baik dan sesuai dengan peraturan yang berlaku, (3) Pada penelitian ini pengukuran variabel kualitas SDM hanya sesuai dengan PP Nomor 71 Tahun 2010, untuk pengukuran variabel kualitas laporan keuangan pemerintah daerah selanjutnya diharapkan dapat mengukur variabel tersebut menggunakan penilaian dari BPK.

\section{REFERENSI}

Abiola, I., \& Oyewole, A. T. 2013. Internal control system on fraud detection: Nigeria experience. Journal of Accounting and Finace, 13(5), pp: 137.

Arfianti, D. 2011. Analisis Faktor-Faktor yang Mempengaruhi Nilai Informasi Pelaporan Keuangan Pemerintah Daerah (Studi Pada Satuan Kerja Pemerintah Daerah di Kabupaten Batang). E-Jurnal akuntansi. Universitas 
Diponegoro.

Connolly, C. \& Hyndman, N. (2006). The Actual Implementation of Accruals Accounting - Caveats from a Case within the UK Public Sector: Accounting, Auditing and Accountability Journal, Vol. 19, No. 2, pp. 272290.

Eisenhardt, K.M. 1989. Agency theory: An assessment and review. Academy of Management Review 14(1): 57-74.

Evacahyani, S. I. 2016. Analisis Faktor-Faktor yang Memengaruhi Kualitas Laporan Keuangan Pemerintah Daerah Kabupaten Tabanan. E-Jurnal Akuntansi Universitas Udayana,5(2), hal. 403-428.

Ghozali, I. 2016. Aplikasi analisis multivariat dengan program SPSS. Badan Penerbit Universitas Diponegoro: Semarang.

Jensen, M. C. \& W. H. Meckling. 1976. Theory of The Firm: Managerial Behavior, Agency Cost and Ownership Structure. Journal of Financial Economics. Vol. 3(4), 305-360

Jones, M. J. 2008. Internal Control, Accountability and Corporate Government: Medieval andModern Britain Compared. Accounting, Auditing and Accountsbility Journal. Vol 21, No 7, pp. 1052-1075

Karbasi, Y, H. \& A. Tarighi (2010). Assessing The Benefits of Accrual Accounting Systems in Medical Sciences and Health Services University of Tehran: Journal of Auditing Knowledge, No. 30, Autumn, pp. 16-27.

Kusuma, F. P. 2016. Analisis Faktor-Faktor yang Mempengaruhi Kualitas Informasi Pelaporan Keuangan Pemerintah Daerah Kabupaten Jembrana. E-Jurnal Akuntansi Universitas Udayana, 5(12), hal. 4115-4150.

Lapsley, I., Mussari, R. and Paulsson, G. (2009). On the Adoption of Accrual Accounting in the Public Sector - A Self-evident and Problematic Reform: Journal European Accounting Review, vol. 18, no. 4, pp. 719-723.

Lillrank, P. 2003. The quality of information. International Journal of Quality \&Reliability Management Vol. 20 No. 6 pp. 691-703

Puspitawati, D. 2016. Analisis Faktor-Faktor yang Memengaruhi Kualitas Laporan Keuangan Pemerintah Daerah. Tesis. Bandar Lampung: Universitas Lampung

Ryan, C., Trevor S., and Morton N. 2002. Accountability Disclosure by Queensland Local Govemment Councils: 1997-1999. Financial 
Accountability \& Management, Vol. 18 (3).

Steccolini, I. 2002. Local Govemment Annual Report: an Accountability Medium. EIASM Conference on Accounting and Auditing in Public Sector Reforms, Dublin, September 2002.

Subrata, I Wayan. 2017. Pengaruh Sistem Pengendalian Intern, Kemampuan Sumber Daya Manusia, dan Pemanfaatan Teknologi Informasi pada Kualitas Laporan Barang Milik Daerah di Pemerintah Kabupaten Gianyar. Tesis. Denpasar: Universitas Udayana

Xu, H., Jeretta H.N., G. Daryl Nord, Binshan Lin. 2003. Key issue of accounting information quality management : Australian case studies. Industrial Management \& Data System 103/7, 461-470

Yosefrinaldi. 2013. Pengaruh Kapasitas Sumber Daya Manusia dan Pemanfaatan Teknologi Informasi Terhadap Kualitas Laporan Keuangan Pemerintah Daerah Dengan Variabel Intervening Sistem Pengendalian Intern Pemerintah (Studi Empiris Pada Dinas Pengelolaan Keuangan dan Aset Daerah Se-Sumatera Barat). Skripsi.Fakultas Ekonomi. Universitas Negeri Padang. Padang.

Yudianta, I G. A., dan Erawati, N. M. A. 2012. Pengaruh Sumber Daya Manusia, Teknologi Informasi dan Pengendalian Intern Terhadap Kualitas Laporan Keuangan. Fakultas Ekonomi. Skripsi. Universitas Udayana. Bali.

Zuliarti. 2012. Pengaruh Kapasitas Sumber Daya Manusia, Pemanfaatan Teknologi Informasi, dan Pengendalian Intern Akuntansi Terhadap Nilai Informasi Pelaporan Keuangan Pemerintah Daerah : Studi Pada Pemerintah Kabupaten Kudus. Skripsi. Universitas Muria Kudus. Kudus.

Peraturan Pemerintah Nomor 71 Tahun 2010 tentang Standar Akuntansi Pemerintah Daerah

Peraturan Pemerintah Nomor 24 Tahun 2005 tentang Standar Akuntansi Pemerintah Daerah

Undang-Undang Nomor 17 Tahun 2003 tentang Keuangan Negara

Badan Pemeriksa Keuangan. 2017. Ikhtisar Hasil Pemeriksaan Semester 1 Tahun 2017. Melalui http://www.bpk.go.id

Pemerintah Kabupaten Ginayar. 2017. Daftar Nama OPD di wilayah Kabupaten Gianyar 2017. Melalui http://www.gianyarkab.go.id 